\author{
EVS24 \\ Stavanger, Norway, May 13-16, 2009
}

\title{
Electrochemical and thermal modeling of lithium-ion cells for use in HEV or EV application
}

\author{
Ralf Benger ${ }^{1}$, Heinz Wenzl ${ }^{1}$, Hans-Peter Beck ${ }^{1}$, Meina Jiang ${ }^{2}$, Detlef Ohms ${ }^{2}$, Gunter \\ Schaedlich ${ }^{2}$ \\ ${ }^{1}$ Institute of Electrical Power Engineering (IEE), Clausthal University of Technology, Leibnizstr 28, 38678 Clausthal, \\ benger@iee.tu-clausthal.de \\ ${ }^{2}$ Hoppecke Battery Systems - Advanced Battery Group, An der Bremecke 4, 59929 Brilon
}

\begin{abstract}
To build a lithium battery system from single cells for use in an electric drive system the coupled electrochemical and thermal characteristics of these cells have to be well-known. Otherwise it is not possible to find the best cell for a given application considering capacity, power, thermal and electric management, housing, monitoring, etc.

In the presented work an easy to parameterize Simulink model regarding the electrochemical and thermal properties was developed to simulate different cell types for an electric drive system. The model is based on an equivalent circuit diagram which is parameterized by means of impedance spectroscopy as well as of current pulse techniques. Differences of these methods are discussed briefly.

By comparing simulation results and measurements it is shown that the coupled electrochemical-thermal model can predict the current - voltage behaviour and the temperature development of the different cells very exactly for both constant current profiles and load profiles appropriate for an electric forklift application.
\end{abstract}

Keywords: electric drive, battery model, simulation, lithium battery

\section{Introduction}

Due to the increased demand for the limited available fossil fuels and increasing environmental concerns, there is great interest worldwide in the use of alternative energy and storage systems for electric or hybrid electric vehicles [1-5].

At the moment, the most favoured technology for storing energy in electric or hybrid vehicles $(\mathrm{EV} / \mathrm{HEV})$ seems to be the lithium-ion or lithium-ion polymer chemistry [1,2,4-6].

Currently there are different efforts to introduce EVs or HEVs into the market. The variety of both lithium chemistries and choice of packaging is wide [7]. Many different cathode chemistries $\left(\mathrm{LiNiCoAlO}_{2}, \mathrm{LiNiMnCoO}_{2}, \mathrm{LiMn}_{2} \mathrm{O}_{4}, \mathrm{LiFePO}_{4}\right.$, etc), a variety of anode materials (graphite natural or synthetic, soft or hard carbon, LTO, etc), the choice of electrolyte (e.g. $\mathrm{LiPF}_{6}$ based, lithiumbis-oxalato borate, ionic liquids $[8,9]$ ) and different cell structures (spirally wound cylindrical and elliptic, stacked plates and wound pouch cells) have to be considered when developing a battery system - initially disregarding safety requirements, costs and aging. 
From the point of view of a developer of battery systems, it is difficult to decide which composition is the best for a given application. In this paper we present an approach to examine different types of lithium cells and to parameterize a coupled electrical-thermal simulation model. By means of the simulations the electrical performance and the thermal behaviour can be predicted and can be used as help selecting cells and designing battery systems.

The extension of the cell model to the whole battery pack including thermal and battery management system, safety requirements, the implementation of aging effects and an analysis of lifetime costs is currently being carried out.

\section{Model development}

The simulation model has to describe the physical correlations between the input parameters, i.e. the current $i$ or power demand $p$ for the lithium cell and the ambient temperature, and the output parameters voltage $u$, state-ofcharge $S O C$ and cell temperature $T_{\text {Cell }}$ for both steady state and dynamic conditions. The model to be developed should be universally valid for the different cell chemistries and packages, easy to parameterize and extendable. Due to this, a Matlab/Simulink model is used which can be easily understood and extended because of its graphical user interface and widespread use.

\subsection{Electrochemical model}

The electrochemical model is based on an equivalent circuit diagram (ECD) which is often used and discussed in the literature. According to Randles [10], many electrical properties of an electrochemical system can be described by elements of an ECD. ECDs are always an approximation due to the high complexity and non-linearity of electrochemical systems but in many applications they reflet the "real worldbehaviour" well.

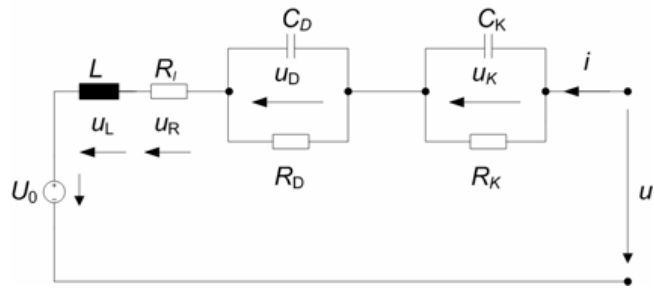

Fig. 1: Conventional ECD for cells to describe the voltage behaviour $u$ as a function of the current $i[10]$.
Fig. 1 shows the ECD suggested by Randles to describe the voltage behaviour $u$ of the cell with two RC couples for charge transfer at the electrode/electrolyte interface (index D) and decrease of voltage due to the reduction of active material (index $\mathrm{K}$ ), an ohmic resistance $R_{\mathrm{I}}$, an inductance $L$ and the open circuit voltage $(O C V)$ source $U_{0}$.

The $O C V$ has to be measured as a function of $S O C$ and the ohmic resistance $R_{\mathrm{I}}$ as a function of $S O C$ and temperature, see chapter 3.3 and 3.4. The temperature influence of the $O C V$ was negligible for the examined lithium cells.

To calculate the charge transfer overpotential $u_{\mathrm{D}}$ eq. (1) is used, with $i_{\mathrm{C}_{\mathrm{D}}}=i-i_{\mathrm{R}_{\mathrm{D}}}$ where $i_{\mathrm{R}_{\mathrm{D}}}$ describes the Tafel kinetics. Values for the exchange current density were taken from the literature [11]. By measuring the voltage response during a current step, the double layer capacity $C_{\mathrm{D}}$ was determined

$u_{\mathrm{D}}=\frac{1}{C_{\mathrm{D}}} \int i_{\mathrm{C}_{\mathrm{D}}}(t) \mathrm{d} t$

The overpotential due to the reduction of active material $u_{\mathrm{k}}$ depends on concentration of reactands respectively $S O C$ and can be expressed as follows in analogy to the battery model proposed by Shepherd [32]:

$u_{k}=i \cdot k \cdot \frac{\operatorname{SOC}(t=0)}{\operatorname{SOC}(t=0)-\operatorname{SOC}(t)}$

$k$ is an experimentally approximated current dependent parameter. This approach avoids time expensive measurements of the second RC couple shown in fig. 1. The simulation results show a good agreement at the end of charging and discharging regimes (chapter 4), so that this approach seems to be reasonable.

The impact of the inductance $L$ in fig. 1 was negligible for the examined cells and the application presented in this work because of relatively slow rates of change of current (chapter 4). For other applications or whole stacks, for example in a HEV, the inductance can be important as well [12]. The determination is possible by the same methods as described in chapter 3 .

\subsection{Thermal model}

Thermal modelling can play an important role to maintain the operating temperature and temperature homogeneity of lithium batteries within an acceptable range [13-16]. There have been many previous efforts on the thermal 
modelling of lithium batteries for electric drive applications [17-19].

In our present work a simplified thermal model is used based on the general energy balance for batteries presented by Bernardi et al [20].

Total heat rate $q$ generated in the cell is the result of Joule heat $q_{\text {Joule }}$ and reversible heat effect $q_{\text {rev }}$ :

$$
\begin{aligned}
& q=q_{\text {Joule }}+q_{\mathrm{rev}} \\
& \text { with } \\
& q_{\text {Joule }}=i \cdot\left(u-U_{0}\right) \\
& \text { and } \\
& q_{\text {rev }}=i \cdot T_{\text {cell }} \cdot \Delta S /(n \cdot F)
\end{aligned}
$$

Eq. 3 represents the heat proportional to entropy change $\Delta S$ with cell temperature $T_{\text {cell }}$, the Faraday constant $F$ and the number of electrons $n$ transferred in the intercalation reaction $(n=1)$.

Heat dissipation from the cell occurs through convective $q_{\alpha}$ and conductive $q_{\lambda}$ heat dissipation and radiation $q_{\varepsilon}$. The energy equation used in the model to calculate the cell temperature $T_{\text {cell }}$ as a function of the ambient temperature $T_{\mathrm{amb}}$ therefore becomes:

$$
\frac{\mathrm{d} T_{\text {cell }}}{\mathrm{d} t}=\frac{1}{m c_{p}}\left[\begin{array}{l}
i \cdot\left(\left(u-U_{0}\right)+\frac{T_{\text {cell }} \cdot \Delta S}{F}\right)- \\
A\left(\begin{array}{l}
\alpha \cdot\left(T_{\text {cell }}-T_{\text {amb }}\right)+\lambda \cdot\left(T_{\text {cell }}-T_{\text {amb }}\right) \\
+\varepsilon \cdot\left(T_{\text {cell }}^{4}-T_{\text {amb }}^{4}\right)
\end{array}\right)
\end{array}\right]
$$

where $\alpha$ is the heat transfer coefficient for forced cooling, $\lambda$ is the conductive heat coefficient, $A$ is the cell surface, $m$ the mass and $c_{\mathrm{p}}$ the specific heat capacity of the cell, $\sigma$ and $\varepsilon$ are the Stefan-Boltzmann constant and the radiation coefficient, respectively. The heat transfer coefficients are both determined experimentally and derived from the literature, see chapter 3.6.

\section{Evaluating the parameters of the model}

\subsection{Examined cells}

Three different cell types are examined in the work presented. Two of them are stacked pouch

\begin{tabular}{|c|c|c|c|}
\hline cell & "1" & "2" & "3" \\
\hline $\begin{array}{c}\text { nominal } \\
\text { voltage [V] }\end{array}$ & 3.6 & 3.6 & 3.6 \\
\hline $\begin{array}{c}\text { nominal } \\
\text { capacity } \\
{[\mathrm{Ah}]}\end{array}$ & 5 & 2.1 & 5 \\
\hline $\begin{array}{l}\text { cathode } \\
\text { material }\end{array}$ & $\begin{array}{c}\mathrm{LiNiMn} \\
\mathrm{CoO}_{2} \\
\end{array}$ & $\begin{array}{c}\mathrm{LiNiMn} \\
\mathrm{CoO}_{2} \\
\end{array}$ & $\begin{array}{c}\mathrm{LiNiMn} \\
\mathrm{CoO}_{2} \\
\end{array}$ \\
\hline $\begin{array}{c}\text { anode } \\
\text { material }\end{array}$ & graphite & $\begin{array}{c}\text { solid } \\
\text { carbon }\end{array}$ & graphite \\
\hline design & $\begin{array}{l}\text { pris- } \\
\text { matic }\end{array}$ & $\begin{array}{l}\text { pris- } \\
\text { matic }\end{array}$ & $\begin{array}{c}\text { cylind- } \\
\text { rical }\end{array}$ \\
\hline
\end{tabular}
cells (sometimes referred to as "coffee-bags"), the third is a spirally wound cylindrical cell. They are produced by different manufacturers and consist of the same cathode material. Details are given in table 1.
Table 1: Examined lithium cells

\subsection{Electrochemical parameters}

To characterize an electrochemical system many different methods are known and are provided by various battery diagnostic methods. They differ by the manner of stimulation and the analysis in the time or in the frequency domain.

In this work two different methods to obtain the values for the ohmic resistance $R_{\mathrm{I}}$ and the double layer capacity $C_{\mathrm{D}}$ are used: (i) Electrochemical impedance spectroscopy (EIS, chapter 3.3) and (ii) Current pulse measurement (chapter 3.4). Both measurements were done for different values of $S O C$ and temperature.

In chapter 5 the results of both techniques will be shown and differences will be discussed briefly.

\subsection{Electrochemical spectroscopy (EIS)}

impedance

EIS is an established and wide spread method to describe the dynamic behaviour of electrochemical systems [21,22]. To evaluate the electrochemical behaviour an electrical stimulus (a known voltage or current) is applied to the system and the response is observed. The transfer from the frequency domain to the time domain is done by Laplace or Fourier transformation [21]. The relation between applied voltage and measured current (or vice versa) is the impedance function of the system,

$$
\underline{Z}(j \omega)=\underline{u}(j \omega) / \underline{i}(j \omega) .
$$

Fig. 2 shows two often used types of illustrations for the impedance and phase angle (top) rsp. the real and the imaginary part (bottom) of $\underline{Z}$ called Bode and Nyquist plots.

The prerequisites for good impedance functions are linearity, causality, stability and finiteness of 
the examined system $[23,24]$. Consequently, the recorded impedance function of a nonlinear system, such as electrochemical systems, is only valid in the neighbourhood of the operating point [22].

But as long as the applied potential difference is less than the thermal voltage, about $25 \mathrm{mV}$ at $25^{\circ} \mathrm{C}$, it can be shown that the basic differential equations which govern the response of the system become linear [21,22].

\section{$\Phi$}

$|Z|$

Fig. 2: Bode (top) and Nyquist (bottom) plot of a stacked pouch lithium cell (type " 2 ", see table 1) at $S O C=1$ and $25^{\circ} \mathrm{C}$

\subsection{Current pulse measurement}

The current pulse or current interrupt technique is frequently used to estimate the various resistances in electrochemical systems $[3,23,25,26]$. In particular for $\mathrm{HEV}$ or $\mathrm{EV}$ applications which require numerous pulses and rest periods this seems to be the most promising method to determine the electrochemical parameters.

To evaluate the ohmic resistance and the resistance for charge transfer at the electrode / electrolyte interface and the double layer capacity the cell was discharged with high pulse currents (due to manufacturer specifications the current was limited to 5C) and the voltage response was measured and analysed. Fig. 3 illustrates the typical voltage response during a current step. The 5C pulse duration is $12 \mathrm{~s}$, followed by a rest period of $60 \mathrm{~s}$ after which there is virtually no further change of voltage.

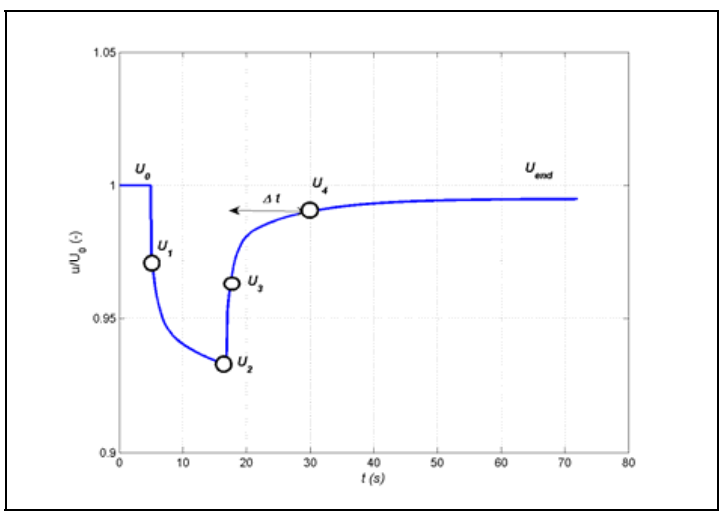

Fig. 3: Typical dimensionless voltage response during a current pulse $(5 \mathrm{C}, 12 \mathrm{~s})$ to determine ohmic resistance and the parameters of the RC couple for charge transfer at the electrode / electrolyte interface, see fig. 1.

The total resistance disregarding long time effects for the voltage response in fig. 3 during a current step can be estimated to:

$R_{\mathrm{tot}}=\frac{U_{0}-u_{2}}{i}$.

The ohmic resistance is:

$R_{\mathrm{I}}=\frac{U_{0}-u_{1}}{i}$

$u_{1}$ and $u_{3}$ were the voltage values one millisecond after $u_{\mathrm{o}}$ and $u_{2}$. This time was chosen as it can be measured easily, but also, because higher resolution measurements indicate that at this time range the general behaviour shown in fig 3 can be measured best. Referring to the ECD in fig. 1 the charge transfer resistance for the short time analysis is the difference between the total and the ohmic resistance:

$R_{\mathrm{D}}=R_{\mathrm{tot}}-R_{\mathrm{I}}$.

The time constant of the RC couple can be approximated by

$$
\tau=\frac{\mathrm{d} t}{\ln \left(1-\frac{U_{4}-U_{3}}{U_{\text {end }}-U_{3}}\right)}
$$

and the double layer capacity therefore becomes: $C_{\mathrm{D}}=\tau / R_{\mathrm{D}}$ 


\subsection{OCV determination}

To determine the $O C V$ as a function of $S O C$, stair step measurements were carried out at different current rates and ambient temperature. The cells were charged and discharged with 1,2 and $4 \mathrm{C}$ at $-10, \quad 025$ and $40^{\circ} \mathrm{C}$. The $O C V$ values were collected in steps of $10 \%$ of SOC after a rest period of $5 \mathrm{~min}$ (in the measurements the impact of the rest period was examined - there were only negligible differences in $O C V$ after $30 \mathrm{~min}$ and $5 \mathrm{~min})$.

The measurements were carried out using a standard battery test system made by Digatron and the cells were placed in a climate chamber at those temperatures.

As an example, in fig. 4 the $O C V$ of cell " 3 " is illustrated as a function of temperature and discharge current. The results show that there is nearly no dependence of the $O C V$ on temperature, current amplitude and current direction. Measurements starting with the discharged cell and then charging in steps of $10 \%$ of SOC provided very similar results. The hysteresis is small and is therefore neglected in the simulations. Cell "1" and "2" show similar behaviour and are not presented here.

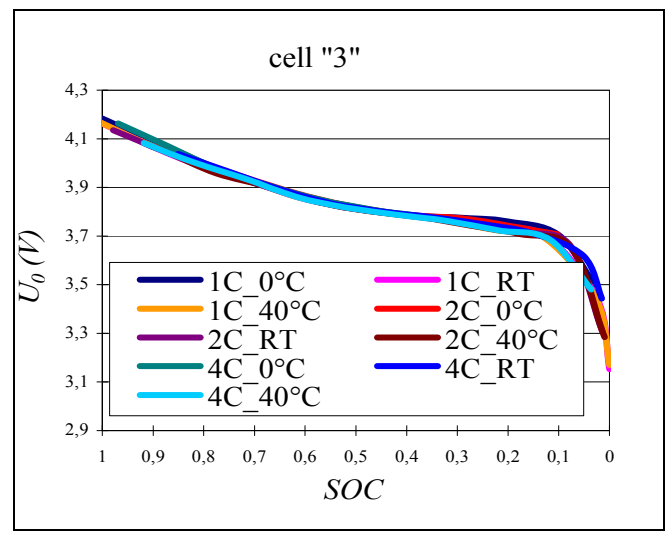

Fig. 4: $O C V$ curves of cell " 3 " as function of temperature and discharge currents $(O C V$ measured $5 \mathrm{~min}$ after discharge regime). The differences are negligible for all examined cells

\subsection{Thermal properties}

To parameterize the thermal model the specific heat capacity, the heat transfer coefficients and the entropic heat have to be determined.

The heat capacities are both estimated by data from the literature and measured with a calorimeter.
Table 2 shows the different heat capacities of the components of the examined cells. The mass fractions were obtained by chemical analyses of the cell composition.

The results of both the measured heat capacities and the heat capacities determined by chemical analyses and data from the literature are listed in table 3 for the examined cells type " 1 " and " 2 ". The spirally wound cell type "3" was not analysed. As can be seen, the heat capacities of the components of the cells show a very good agreement with the measured values and other values published in the literature [19].

The heat transfer coefficients of the cells were calculated under the assumption that the heat exchange with the environment through conduction is sufficiently small to neglect these terms. The heat transfer by convection is calculated for forced and free convection. The heat transfer is a function of the dimensionless variables Reynolds-Number, Prandtl-Number, Grashof-Number and Rayleigh-Number and can be calculated with tabled equations [27] for the different geometries.

Table 2: Specific heat capacities of the components of the examined cells [28]

\begin{tabular}{|c|c|}
\hline Material & $\begin{array}{c}\text { Specific heat } \\
{\left[\mathrm{J} \cdot \mathrm{g}^{-1} \cdot \mathrm{K}^{-1}\right]}\end{array}$ \\
\hline $\mathrm{Li}$ & 3.582 \\
\hline $\mathrm{Co}$ & .449 \\
\hline $\mathrm{Al}$ & .903 \\
\hline $\mathrm{Cu}$ & .385 \\
\hline $\mathrm{Ni}$ & .444 \\
\hline $\mathrm{Fe}$ & .452 \\
\hline $\mathrm{Mn}$ & .473 \\
\hline $\mathrm{F}$ & .824 \\
\hline $\mathrm{P}$ & .769 \\
\hline Graphite & .709 \\
\hline $\mathrm{Al}_{2} \mathrm{O}_{3}$ & .765 \\
\hline $\mathrm{SiO}_{2}$ & .745 \\
\hline PP & 1.700 \\
\hline mat & 1.400 \\
\hline
\end{tabular}


Table 3: Measured and determined heat capacities of cell "1" and " 2 "

\begin{tabular}{|c|c|c|}
\hline cell & “1” & “2” \\
\hline heat capacity $[\mathrm{J} / \mathrm{K}]$ & 88.29 & 72.93 \\
\hline weight $[\mathrm{g}]$ & 93.43 & 78.34 \\
\hline $\begin{array}{c}\text { specific heat capacity } \\
\text { (from literature) } \\
{\left[\mathrm{J} \cdot \mathrm{g}^{-1} \cdot \mathrm{K}^{-1}\right]}\end{array}$ & 0.95 & 0.93 \\
\hline $\begin{array}{c}\text { specific heat capacity } \\
(\text { measured average) } \\
{\left[\mathrm{J} \cdot \mathrm{g}^{-1} \cdot \mathrm{K}^{-1}\right]}\end{array}$ & 0.975 & 0.90 \\
\hline
\end{tabular}

The heat transfer by radiation (last term in eq. 4) can be approximated for small temperature differences $(<20 \mathrm{~K})$ to [29]:

$$
q_{\varepsilon}=A \cdot\left(T_{\text {cell }}-T_{\text {amb }}\right) \cdot 5 \frac{W}{m^{2} K} \text {. }
$$

\section{Results}

The determined electrochemical and thermal parameters (chapter 3) were implemented in the Matlab/Simulink simulation model (chapter 2).

Constant current discharges (chapter 4.1), pulse current discharges (chapter 4.2) and cycle tests (chapter 4.3), appropriate for a forklift truck application, were carried out and compared with the results of the simulations to verify the electrochemical and thermal simulation model.

All three types of cells (table 1) were investigated, in this paper only the results of the pouch cells with $2.1 \mathrm{Ah}$ (cell " 2 ") and $5 \mathrm{Ah}$ (cell " 1 ") at room temperature are shown. The results of the other examined cell type and different ambient temperatures showed similar agreements between measurement and simulation and are therefore not shown here.

\subsection{Constant current discharge}

In fig. 5 the measured and simulated values during discharging at rated currents of $1 \mathrm{C}, 2 \mathrm{C}$ and $5 \mathrm{C}$ for the $2.1 \mathrm{Ah}$ pouch cell are given. The comparison of measured and simulated values of the cell voltage shows that the model gives a good estimation of voltage behaviour of the cell. Please note that the value $k$ which is experimentally fitted (see chapter 2.1) is the same for all discharge curves and that the other parameters of the model are not taken from constant current discharge curves.

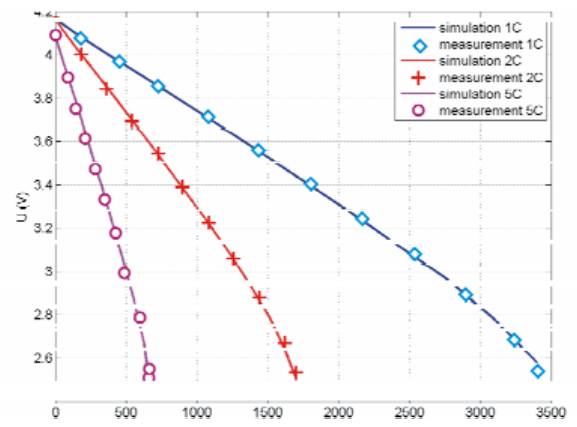

Fig. 5: Measured and simulated voltages during different rates of discharge current of cell "2" at room temperature.

\subsection{Pulse current discharge}

To evaluate the ohmic resistance, the charge transfer resistance and the double layer capacity, the cells were discharged with pulse currents and the voltage response was measured (see chapter 3.4). The discharge pulses had a rated current of $5 \mathrm{C}$ for $12 \mathrm{~s}$, followed by a rest period of one minute. 55 pulses were possible before the minimum discharge voltage of $2.5 \mathrm{~V}$ was reached. The amount of discharge equals $90 \%$ of the nominal capacity of 2.1Ah (1C).

To avoid temperature influence the cell was discharged under forced cooling (pseudoisothermal). Fig. 6 shows the measured and simulated voltage behaviour during the current pulses. 


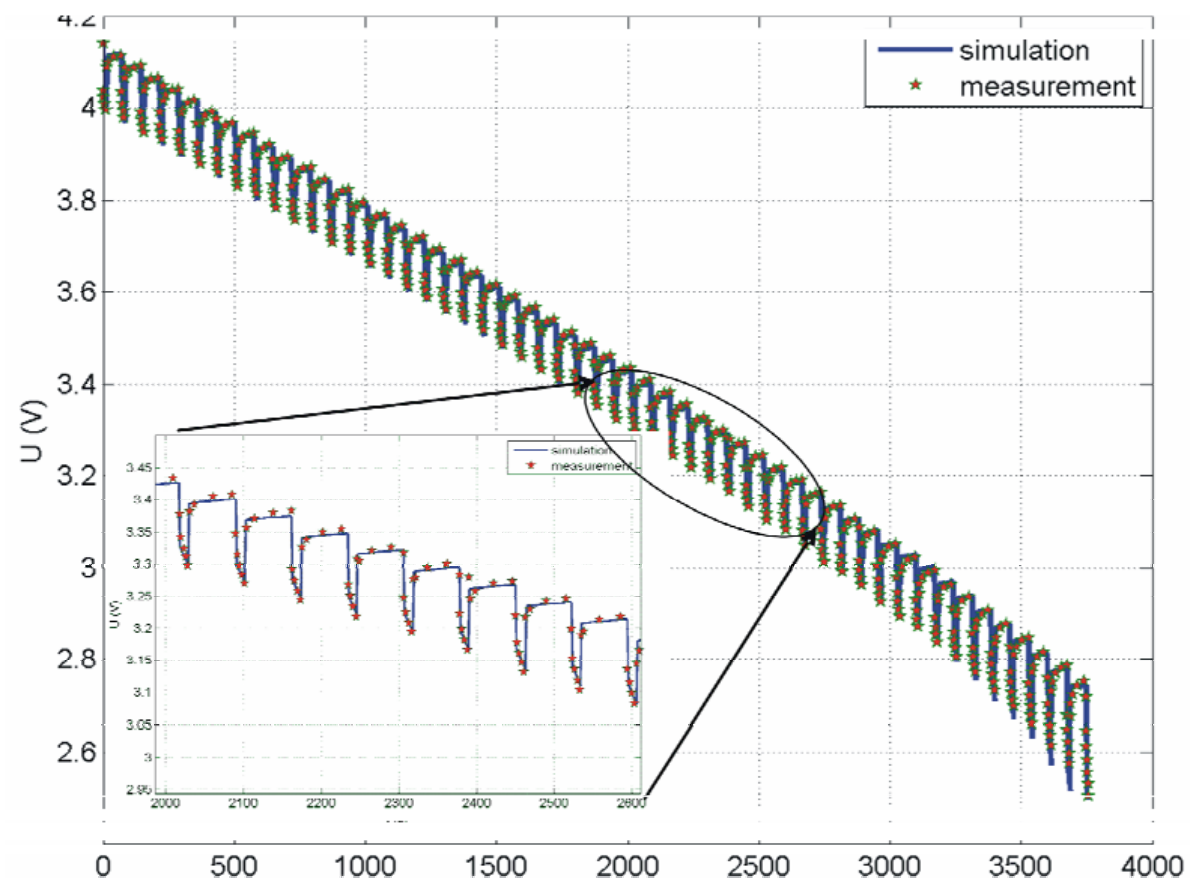

Fig. 6: Measured and simulated voltages during pulse currents (rated current 5C) of cell " 2 " at room temperature under forced cooling conditions.

\subsection{Cycling with a current profile of an electric forklift}

The profile of an electric forklift was measured, slightly simplified and used as a reference value for a standard battery test system to examine the cells in this special application.

The profile of the electric forklift equates an $8 \mathrm{~h}$ working shift with a rest period of 20 minutes after 400 cycles (approx. 4h), total number of cycles was 723 .

Each cycle of 33 s consists of 1 s $0 \mathrm{~A}, 10$ s driving at $-0.375 \mathrm{~A}, 6 \mathrm{~s}$ lifting at $-5 \mathrm{~A}, 1 \mathrm{~s} 0 \mathrm{~A}, 3 \mathrm{~s}$ recuperative braking at $3.75 \mathrm{~A}, 1 \mathrm{~s} 0 \mathrm{~A}$ and $11 \mathrm{~s}$ standing at $-0.06 \mathrm{~A}$ (negative sign for discharging), see fig. 7 top.

As can be seen, there are only small differences between measured and simulated cell voltages. Moreover, the voltage and thermal behaviour can be predicted very exactly over a wide time range for the applied current profile, see fig. 8.

The results of the simulations of cell types " 2 " and " 3 " are similar to the results of cell type " 1 " shown in fig. 8. The standard deviation between the measured and simulated values of the cell voltage is smaller than $20 \mathrm{mV}$ for all kinds of examined cell types for the described application.
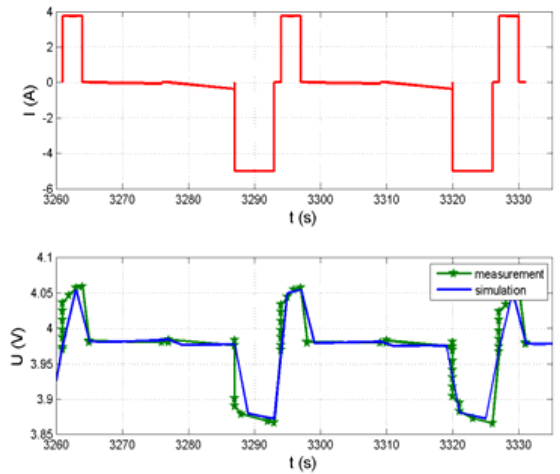

Fig. 7: Section of current profile of an electrical forklift application (top) and measured and simulated voltages (bottom) for the $5 \mathrm{Ah}$ pouch cell at room temperature. 

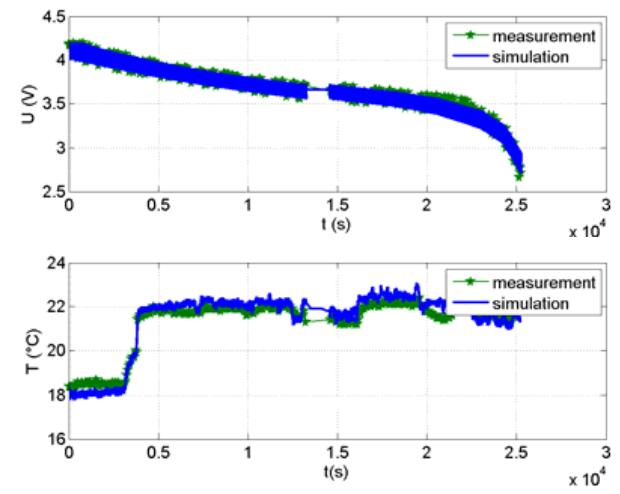

Fig. 8: Comparison of measured and simulated cell voltage (top) and temperature (bottom) for a whole working shift of an electric forklift for cell type " 1 " at room temperature. At approx. 3000s the external heating installation was switched on and the ambient temperature increased.

The accuracy of the thermal model is satisfactory; the maximum deviation is smaller than $2.5 \mathrm{~K}$ for the three cells. But it must be considered that the overall heat generation was low in this application under forced cooling conditions.

The absolute error in temperature for the electric forklift application is illustrated in fig. 9 for cell type " 1 ".

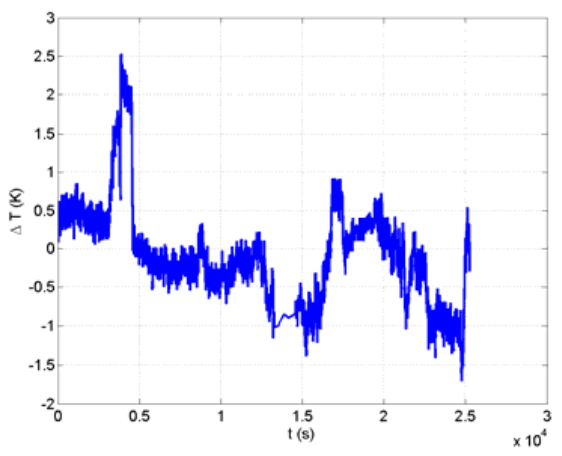

Fig. 9: Absolute error in temperature between measurement and simulation calculated for cell type "1" for the electric forklift application (current profile shown in fig. 7). Measurement taken at room temperature and forced cooling condition.

\section{Discussion}

The comparison of measured and simulated data parameterized by EIS or pulse current technique showed that the results were more exact when using the second method. It seems to be obvious that the determination of the parameters of the ECD should be better using current pulse techniques for applications with numerous changes of power and current with non-marginal amplitudes.

As mentioned before the prerequisites for good impedance functions are linearity, causality, stability and finiteness of the examined system $[23,24]$. At least it is questionable if a determination by EIS is the right method especially for an electric drive system where currents are outside the linear range.

Fig. 10 shows the measured time depending resistances of two spirally wound lithium-ion cells made by GAIA with 6 rsp. 27Ah capacity during different rates of currents to emphasize the impact of the measuring method. At very small currents, the values determined by both methods agree, but at very high currents, the value determined by the current pulse method is significantly different.

A detailed discussion can be found in [12,30,31] Further analyses are currently being carried out.

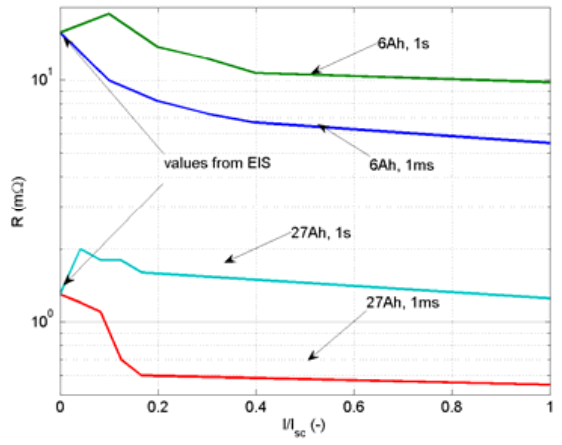

Fig. 10: Current and time depending resistances of spirally wound lithium cells with $6 \mathrm{Ah}$ and $27 \mathrm{Ah}$.

Dimensionless current is referred to the short circuit current $\mathrm{I}_{\mathrm{sc}}$ of the cells (502A for the $6 \mathrm{Ah}$ cell, $1029 \mathrm{~A}$ for the 27Ah cell). 
It is mentioned above that the determination of the parameter $k$ (eq. 2) to describe the decrease of voltage due to the reduction of active material occurs experimentally and current dependent. This approach avoids time expensive measurements of the second RC couple shown in fig. 1. The simulation results show a good agreement at the end of charging and discharging regimes, so that this approach seems to be reasonable.

By using a current independent value for $k$ it can be shown that the results of the simulations are equal to the results if the parameter is determined current dependent in the practical SOC range from 0.9 to 0.1 for an electric drive cycle.

\section{Conclusions}

By means of simulation the electrical performance and the thermal behaviour can be predicted very exactly for the examined current and temperature range and can be used as help for selecting cell types and designing battery systems.

The extension of the cell models to the whole battery pack including thermal and battery management system, safety requirements, the implementation of aging effects and an analysis of lifetime costs are currently being carried out.

\section{References}

[1] D. Naunin (edit), Hybrid-, Batterie- und Brennstoffzellen-Elektrofahrzeuge, 3. Auflage 2004, ISBN 978-3-8169-2625-2, Germany, expert Verlag, 2004

[2] Moss et al. An electrical circuit for modeling the dynamic response of li-ion polymer batteries, Journal of the Electrochemical Society 155 (12) (2008), A986-A994

[3] D. Ohms et al., Alkaline High Power Batteries in Bipolar Stack Design, Journal of Power Sources 96 (2001), 76-84

[4] B. Kennedy et al., Use of lithium-ion batteries in electric vehicles, Journal of Power Sources 90 (2000), 156-162

[5] VARTA Spezial Report, Hochleistungsbatterien für neue Fahrzeuganwendungen, 2006

[6] Kahaian et al: Development of a high-power lithium-ion battery, Journal of Power Sources 81 (1999), p. 902

[7] M. Anderman: Status of Worldwide HEVs, EVs and their Energy-Storage Technology and Market Development, Symposium Advanced Battery Technologies for Automobiles and their Electric Grid Integration, 20-21 Jan. 2009, Essen, Germany

[8] M. Schmidt: Electrolytes for Lithium-Ion Batteries-State of The Art, Symposium Advanced Battery Technologies for Automobiles and their Electric Grid Integration, 20-21 Jan. 2009, Essen, Germany

[9] M Winter: Introduction Into Li-Ion Battery Materials, Symposium Advanced Battery Technologies for Automobiles and their Electric Grid Integration, 20-21 Jan. 2009, Essen, Germany

[10] J. Randles: Kinetics of rapid electrode reactions, Discuss. Faraday Soc. (1), pp 1119, 1947

[11] J. Newman et al: Double-layer capacitance in a dual lithium insertion cell, Journal of the Electrochemical. Society. 142 (12) (1999), p. 4360

[12] R. Benger et al: Behaviour of electrochemical systems like lithium-ion, NiMH, lead-acid batteries and super capacitors during fast current steps, 3rd European Ele-Drive Transportation Conference, 11th - 13th March 2008, Geneva

[13] Kim et al: Effect of electrode configuration on the thermal behaviour of a lithium-polymer battery, Journal of Power Sources 180 (2007), 909-916

[14] G. Cedar et al: ComputationalModeling and Simulation for rechargeable Batteries, Material Research Society, Bull. 27, (2002), 619-623

[15] J. Newman et al: Modeling of Lithium-ion Batteries, Journal of Power Sources 119-121 (2003), 838-843

[16] Y. Chen et al: Thermal Analysis of Lithium Polymer Electrolyte Batteries by a two dimensional Model, Electrochimica Acta 39 (1994), 517-526

[17] C. Pals, J. Newman: Thermal modeling of the Lithium/Polymer Battery, Journal of the Electrochemical Society. 142 (10) (2006), p. 3274-3281 and 3282-3288

[18] K. Smith, C.-Y. Wang: Power and thermal characterization of a lithium-ion battery pack for hybrid-electric vehicles, Journal of Power Sources 160 (2006), 662-673

[19] K. Onda et al: Thermal behavior of small lithium-ion battery during rapid charge and discharge cycles, Journal of Power Sources 158 (2006) p. 535-542 
[20] D. Bernardi et al: A General Energy Balance for Battery Systems, Journal of the Electrochemical Society 132 (5) (1985), 512

[21] K. Onda et al: Cell impedance measurement by Laplace transformation of charge and discharge current-voltage, Journal of the Electrochemical Society. 153 (6) (2006), A1012-A1018

[22] J.R. MacDonald edit.: Impedance Spectroscopy, ISBN 0-471-64749-7, New Jersey, John Wiley \& Sons, 2005

[23] M.A. Danzer, E.P. Hofer: Electrochemical parameter identification - An efficient method for fuel cell impedance characterisation, Journal of Power Sources 183 (1) (2008), 55-61

[24] A. Lasia et al: Electrochemical Impedance Spectroscopy and its applications, in: Modern Aspects of Electrochemistry (32),143-248, ISSN 0076-9924, New York, Kluwer Academic, 1999

[25] V. Srinivasan: Mathematical Modeling of Current-Interrupt and Pulse Operation of Valve-Regulated Lead-Acid Cells, Journal of the Electrochemical Society 150 (3) (2003), A316-A325

[26] K. Cooper, M. Smith: Electrical test methods for on-line fuel cell ohmic resistance measurement, Journal of Power Sources 160 (2006), 1088-1095

[27] Verein Deutscher Ingenieure: VDIWärmeatlas, ISBN 978-3-540-32218-4 Berlin-Heidelberg-New York, Springer Verlag, 2006

[28] H.D. Baehr, K. Stefan: Wärme- und Stoffübertragung, ISBN 978-3-540-325109, Berlin-Heidelberg, Springer-Verlag, 2006

[29] D. Berndt: Maintenance-Free Batteries, ISBN 0-86380-279-6, Baldock, Eng. Research Studies Press Ltd., 2003

[30] A. Haubrock, R. Benger, H.-P. Beck, H. Wenzl: Characterizing electrochemical systems used for high-current application by measuring the short circuit current and the internal resistance, to be published, EVS24, Stavanger, Norway, 13-16 May 2009

[31] R. Benger, H. Wenzl, H.-P. Beck, C. Ropeter: The impact of very fast current changes on electrochemical systems, etz ISSN 0948-7387, 129.08, 3, 54-61, VDEVerlag GmbH, Berlin, 2008
[32] C.M. Shepherd: Design of Primary and Secondary Cells II. An Equation Describing Battery Discharge, Journal of the Electrochemical Society. 112 (1965), 657-664

\section{Authors}

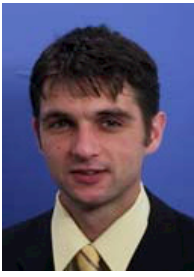

Dipl.-Ing. Ralf Benger graduated as power systems engineer at the Clausthal University of Technology (TU) in 2004.

$\mathrm{He}$ is looking for his $\mathrm{PhD}$ by examining the dynamic behaviour of electrochemical systems. Currently he deals with a research project founded by the German Research Foundation. Dipl.-Ing. Meina Jiang studied

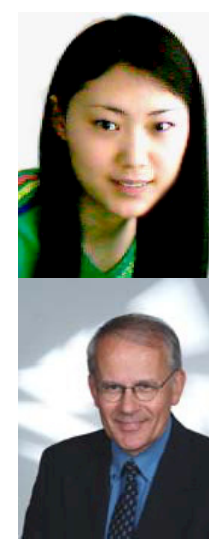
Mechanical Engineering at TU of Liaoning./China. She graduated as power systems engineer at the $\mathrm{TU}$ Clausthal/Germany in 2008.

Recently she is looking for a Ph.D. at Hoppecke $\mathrm{GmbH}$ in collobaration with the TU Dresden by examining lithiumion batteries.

Dr. rer. nat. Heinz Wenzl studied physics at the Technical University of Munich; $\mathrm{He}$ is a lecturer at the Institute of Electrical Engineering of the TU Clausthal and a consultant specialising in batteries and decentralised energy technologies.

Dr. Ing. Hans-Peter Beck is Professor for electrical engineering and electrical power engineering since 1989, since 1990 director of the Institute of Electric Power Engineering of TU Clausthal and the vice president for research and development of the university. Since 2008 he is also the director of the Energy Research Centre of Niedersachsen (EFZN).

Dr. Gunter Schaedlich

$\mathrm{PhD}$ at University of Dresden, Doctor thesis: Self-discharge and passivity phenomena on $\mathrm{PbO}_{2}$ Electrodes.

Several positions in industry at $R \& D$ as Manager and Managing Director

Actual: Director of Advanced Technologies at HOPPECKE Batterien $\mathrm{GmbH} \& \mathrm{Co} . \mathrm{KG}$ Dr. Detlef Ohms

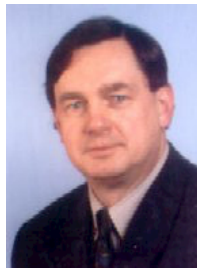

$\mathrm{PhD}$ at TU Dresden in Electrocatalysis. Research work into Fuel Cells, Batteries for electric vehicles and industrial batteries at ZSW Ulm, Deutsche Automobilgesellschaft Stuttgart and Hoppecke Batterie Systeme $\mathrm{GmbH}$ Brilon. 